Scientific paper

\title{
Synthesis, Crystal structure, and Hirshfeld Surface Analysis of a New Mixed Ligand Copper(II) Complex
}

\author{
Shyamapada Shit, ${ }^{1,2}$ Christoph Marschner ${ }^{3}$ and Samiran Mitra ${ }^{1, *}$ \\ ${ }^{1}$ Department of Chemistry, Jadavpur University, Kolkata-700 032, India \\ ${ }^{2}$ Department of Chemistry, Jalpaiguri Government Engineering College, Jalpaiguri-735 102, West Bengal, India \\ ${ }^{3}$ Institut für Anorganische Chemie, Technische Universität Graz, Austria \\ * Corresponding author: E-mail: samiranju92@gmail.com
}

Received: 02-10-2015

\begin{abstract}
A new mixed ligand copper(II) complex, $\left[\mathrm{Cu}(2,4-\mathrm{pydc})(\right.$ pic $\left.)\left(\mathrm{H}_{2} \mathrm{O}\right)\right] \cdot \mathrm{H}_{2} \mathrm{O}(\mathbf{1})$ (where 2,4-pydc $=$ pyridine-2,4-dicarboxylate, pic $=2$-picolylamine) has been synthesized and characterized by elemental analysis, FT-IR and UV-Vis spectroscopic and thermogravimetric methods. Single crystal X-ray diffraction analysis reveals that copper(II) atom in the title complex adopts distorted square-pyramidal geometry. Structural characterization also reveals that interplay of $\mathrm{O}-\mathrm{H} \cdots \mathrm{O}, \mathrm{N}-\mathrm{H} \cdots \mathrm{O}, \mathrm{C}-\mathrm{H} \cdots \mathrm{O}$, and $\mathrm{C}-\mathrm{H} \cdots \pi$ interactions between lattice and coordinated water and ligands significantly contribute to the crystal packing leading to the formation and strengthening of three dimensional supramolecular assembly. Hirshfeld surface analysis employing 3D molecular surface contours and 2D fingerprint plots have been used to analyze intermolecular interactions present in the solid state of the crystal.
\end{abstract}

Keywords: Copper(II) complex, Crystal structure, Hydrogen bonding, Hirshfeld surface analysis, TGA study

\section{Introduction}

Metal-organic coordination compounds based on aromatic multicaboxylic acid have been studied extensively due to their interesting geometrical and topological features along with their potential applications in many areas including gas storage, separation, catalysis, magnetism and optics. ${ }^{1}$ The nature of the metal ions, selection of the appropriate aromatic multicarboxylic acid, and modulation of the reaction conditions are the important factors to achieve a desire target compound with specified physical properties. ${ }^{2}$ Among various aromatic multicarboxylic acids, the class constituting $N$-heterocyclic multicarboxylic acids such as pyridine-, pyrazine-, and pyrazole-polycarboxylic acids and/or their derivatives ${ }^{3-12}$ have been extensively employed for their simultaneous chelating capability and diverse coordination abilities. In this regard, pyridine-2,4-dicarboxylate ligand demands special attention not only for both the carboxylate group and nitrogen atom but also for not providing steric hindrance, which makes it versatile for the formation of novel metal-organic frameworks. ${ }^{1}$ However, the introduction of nitrogen-con- taining neutral organic spacers containing two or more pyridyl groups separated by rigid or flexible spacers, such as 4,4'-bipyridine, 1,2-bis(4'-pyridyl)ethane/ethene, 1,2-bis(4'-pyridyl)propane etc. have been used to generate an affluent variety of metal organic architectures. ${ }^{13-16}$ On the other hand, introduction of nitrogen-containing organic blocker containing two nitrogen atoms such as $2,2^{\prime}$-bipyridine, ${ }^{17} \quad 1,10$-phenanthroline, ${ }^{2,18}$ and $N, N, N^{\prime}, N^{\prime \prime}, N^{\prime \prime}$-pentamethylethylenetriamine ${ }^{16}$ etc, have often been used to achieve restricted structures. Thus, demonstration of the auxiliary co-ligand plays an important role in determining the final architectures.

Moreover, due to the presence of various nitrogen and oxygen atoms and rich aromatic backbone, $\mathrm{N}$-heterocyclic multicarboxylic acids often act as molecular building block for self-assembly through various intermolecular interactions as hydrogen bonding, $\pi-\pi$ stacking, etc. ${ }^{19-21}$ Analysis of these interactions is important to understand how molecules interact with their direct environment and focus insight into crystal packing behavior. Hirshfeld surface based tools appear as a novel approach to this problem..$^{22-27}$ The central element in this method is 
the derivation of the Hirshfeld surface, an immediately interpretable visualization of a molecule within its environment, and the decomposition of this surface to provide a 'molecular fingerprint'- a directly accessible 2D map ${ }^{22,28,29}$ that provides the full distribution of interactions. The former, in addition to being an invaluable visualization tool, provides a basis for quantitative analysis of molecular properties for comparison with bulk measurement while the latter allows convenient comparison between molecules in different environments. ${ }^{20}$

Herein we have reported a new mixed ligand copper(II) coordination complex $\left[\mathrm{Cu}(2,4-\right.$ pydc $)($ pic $\left.)\left(\mathrm{H}_{2} \mathrm{O}\right)\right]$. $\mathrm{H}_{2} \mathrm{O}$ (1), derived from 2,4-pydc and a neutral $N, N$-donor pyridyl blocker, 2-pycolylamine (pic), and characterized by elemental analyses, FT-IR and UV-Vis spectroscopic, and thermogravimetric methods. Single crystal X-ray structural analysis of 1 reveals five coordinated distorted square-pyramidal geometry for copper(II) atom. The molecular unit is involved in extensive hydrogen bonding to each other leading to interesting supramolecular structures which are further stabilized by weak $\mathrm{C}-\mathrm{H} \cdots \pi$ interaction. Hirshfeld surface analysis is used to analyze the intermolecular interactions present in the solid state of the compound.

\section{Experimental Section}

\section{1. Materials and Instrumentations}

All chemicals and solvents used for the synthesis were of AR grade. Triethylamine, copper(II) nitrate trihydrate, were obtained from E. Merck, India. Pyridine-2,4dicarboxylic acid and 2-picolylamine (2-aminomethylpyridine) were purchased from Aldrich Chemical Co. All chemicals were used without further purification. Elemental analyses (carbon, hydrogen and nitrogen) were performed with a Perkin Elmer 2400 II Elemental Analyser. Copper(II) content of $\mathbf{1}$ has been estimated quantitatively by standard iodometric procedure. The Fourier transform infrared spectrum was recorded on a Perkin Elmer RX-I FT-IR spectrophotometer, with solid $\mathrm{KBr}$ disc, in the range $4000-400 \mathrm{~cm}^{-1}$. Solid state UV-Vis spectrum of the title complex was recorded on a Perkin Elmer Lambda $35 \mathrm{UV}-\mathrm{Vis}$ system in the range $1100-200 \mathrm{~nm}$. TG analysis was performed with a Perkin-Elmer (Singapore) Pyris Diamond TGA unit. Thermal study was performed at the temperature range $35-800{ }^{\circ} \mathrm{C}$ by maintaining the heating rate at $5{ }^{\circ} \mathrm{C} \mathrm{min}^{-1}$ in a stream of nitrogen flowing at the rate of $50 \mathrm{~mL} \mathrm{~min}{ }^{-1}$ with the sample in a platinum crucible. Powder X-ray diffraction was performed on a Bruker D8 instrument with $\mathrm{Cu}-\mathrm{K} \alpha$ radiation.

\section{2. Synthesis of $\left[\mathrm{Cu}(2,4-p y d c)(\right.$ pic $\left.)\left(\mathrm{H}_{2} \mathrm{O}\right)\right] \cdot$ $\mathrm{H}_{2} \mathrm{O}$ (1)}

Pyridine-2,4-dicarboxylic acid ( $1.0 \mathrm{mmol}, 0.167 \mathrm{~g})$ was dissolved in $25 \mathrm{~mL}$ of water with the dropwise addi- tion of triethylamine ( $2.0 \mathrm{mmol}, 0.105 \mathrm{~g})$. To the resulting solution a methanolic solution $(20 \mathrm{~mL})$ of copper(II) nitrate trihydrate $(1.0 \mathrm{mmol}, 0.242 \mathrm{~g})$ was slowly added with constant stirring. After 10 minutes, a methanolic solution $(10 \mathrm{~mL})$ of 2-picolylamine $(1.0 \mathrm{mmol}, 0.180 \mathrm{~g}$, was added dropwise. The $\mathrm{pH}$ of the mixture was adjusted to $\sim 7-8$. The resulting solution was refluxed for 1 hour and then filtered. The filtrate was left undisturbed. Blue plate shaped crystals of 1 suitable for X-ray diffraction were obtained after five days. Yield: $84 \%$ with respect to the metal substrate. $\mathrm{C}_{13} \mathrm{H}_{15} \mathrm{CuN}_{3} \mathrm{O}_{6}$ (FW: 372.83): Calcd. C, 41.88; H, 4.06; N, 11.27, Cu, 17.04\%. Found: C, 41.82; $\mathrm{H}, 4.01 ; \mathrm{N}, 11.26 ; \mathrm{Cu} ; 17.00 \%$.

\section{3. X-ray Crystallography}

Diffraction quality, air stable, plate shaped blue crystal of 1 was mounted on Bruker SMART APEX CCD diffractometer equipped with fine focus sealed tube graphite-monochromator bearing molybdenum target $\left(\lambda_{\mathrm{MoK} \alpha}=\right.$ $0.71073 \AA$ A). Crystal data for 1 were collected using Bruker SMART software ${ }^{30}$ at 100(2) K using $\omega$ scan technique. Cell refinement for $\mathbf{1}$ was carried out using Bruker SMART program. ${ }^{31}$ No significant intensity variations were observed during the data collection. Multi-scan absorption correction was applied to the intensity values $\left(T_{\max }=0.7259, T_{\min }=0.5611\right)$ empirically using SADABS. ${ }^{31}$ Data reduction for $\mathbf{1}$ were performed using Bruker SAINT. ${ }^{32}$ Crystal structure of $\mathbf{1}$ was solved by direct met-

Table 1. Crystal data and structure refinement parameters for $\mathbf{1}$

\begin{tabular}{|c|c|}
\hline Crystal data & 1 \\
\hline Empirical formula & $\mathrm{C}_{13} \mathrm{H}_{15} \mathrm{CuN}_{3} \mathrm{O}_{6}$ \\
\hline Formula weight $\left(\mathrm{g} \mathrm{mol}^{-1}\right)$ & 372.83 \\
\hline Crystal size $\left(\mathrm{mm}^{3}\right)$ & $0.22 \times 0.28 \times 0.42$ \\
\hline Cell setting, Space group & Monoclinic, $P 2_{1} / c$ \\
\hline \multirow[t]{4}{*}{ Unit cell dimensions } & $a=10.556(2) \AA$ \\
\hline & $b=19.379(4) \AA$ \\
\hline & $c=7.0474(14) \AA$ \\
\hline & $\beta=94.02(3)^{\circ}$ \\
\hline Unit cell volume & $1438.1(5) \AA^{3}$ \\
\hline$T(\mathrm{~K})$ & $100(2)$ \\
\hline$Z$, Density $\left[\mathrm{g} / \mathrm{cm}^{-3}\right]$ & $4,1.722$ \\
\hline Absorption coefficient & $1.556 \mathrm{~mm}^{-1}$ \\
\hline$F(000)$ & 764 \\
\hline Reflection collected/ unique & $11304 / 2927\left[R_{\mathrm{int}}=0.045\right]$ \\
\hline Observed data $[I>2 \sigma(I)]$ & 2692 \\
\hline$N_{\text {ref }} ; N_{\mathrm{par}}$ & $2927 ; 224$ \\
\hline Final $R$ indices $[I>2 \sigma(I)]^{(\mathrm{a})}$ & $R_{1}=0.0445$ \\
\hline & $w R_{2}=0.0970$ \\
\hline$R$ indices (all data) ${ }^{(\mathrm{a})}$ & $R_{1}=0.0498$ \\
\hline & $w R_{2}=0.0996$ \\
\hline Goodness-of-fit on $F^{2}$ & 1.14 \\
\hline Largest diff. Peak and hole & 0.50 and -0.45 \\
\hline
\end{tabular}

${ }^{(a)} R=\Sigma\left(\mid F_{o}-F_{c}\right) / \Sigma\left|F_{o}\right|, w R=\left\{\Sigma\left[w\left(\mid F_{o}-F_{c}\right)^{2}\right]^{2} / \Sigma\left[w\left|F_{o}\right|^{2}\right]\right\}^{1 / 2}$. 
hods using the program SHELXS- $97^{33}$ and refined with full-matrix least-squares based on $F^{2}$ using SHELXL$97 .{ }^{33}$ The non-hydrogen atoms were refined with anisotropic displacement parameters. Water hydrogen atoms were treated freely while all other hydrogen atoms were first located in the Fourier difference map, then positioned geometrically and allowed to ride on their respective parent atoms and refined with isotropic thermal parameters. The molecular graphics and crystallographic illustrations were prepared using ORTEP ${ }^{34}$ and Bruker SHELXTL. ${ }^{35}$ Details concerning crystal data and refinement parameters for $\mathbf{1}$ are summarized in Table 1.

\section{4. Hirshfeld Surfaces Calculations}

Hirshfeld surface analysis serves as a powerful tool for gaining additional insight into the intermolecular interaction of molecular crystals. The size and shape of Hirshfeld surface allows the qualitative and quantitative investigation and visualization of intermolecular close contacts in molecular crystals. ${ }^{36}$ The Hirshfeld surface enclosing a molecule is defined by a set of points in 3D space where the contribution to the electron density from the molecule of interest is equal to the contribution from all other molecules. Molecular Hirshfeld surfaces are constructed based on electron distribution calculated as the sum of spherical atom electron densities. ${ }^{24,37}$ Thus, an isosurface is obtained, and for each point of the isosurface two distances can be defined: $d_{\mathrm{e}}$, the distance from the point to the nearest atom outside to the surface, and $d_{\mathrm{i}}$, the distance to the nearest atom inside to the surface. Moreover, the identification of the regions of particular importance to intermolecular interactions is obtained by mapping normalized contact distance $\left(d_{\text {norm }}\right)$, expressed as: $d_{\text {norm }=}\left(d_{\mathrm{i}}-r_{\mathrm{i}}^{\mathrm{vdw}}\right) / r_{\mathrm{i}}^{\mathrm{vdw}}+$ $\left(d_{\mathrm{e}}-r_{\mathrm{e}}^{\mathrm{vdw}}\right) / r_{\mathrm{e}}^{\mathrm{vdw}}$; where $r_{\mathrm{i}}^{\mathrm{vdw}}$ and $r_{\mathrm{e}}^{\mathrm{vdw}}$ are the van der Waals radii of the atoms. ${ }^{23}$ The value of $d_{\text {norm }}$ is negative or positive when intermolecular contacts are shorter or longer than $r^{\mathrm{vdw}}$, respectively. Graphical plots of the molecular Hirshfeld surfaces mapped with $d_{\text {norm }}$ employ the red-white-blue colour scheme where red colour indicates the shorter intermolecular contacts, white colour shows the contacts around the $r^{\mathrm{vdW}}$ separation, and blue colour is used to indicate the longer contact distances. Because of the symmetry between $d_{\mathrm{e}}$ and $d_{\mathrm{i}}$ in the expression for $d_{\text {norm }}$, where two Hirshfeld surfaces touch, both will display a red spot identical in colour intensity as well as size and shape. ${ }^{38}$

The combination of $d_{\mathrm{e}}$ and $d_{\mathrm{i}}$ in the form of a 2D fingerprint plot provides summary of intermolecular contacts in the crystal and are in complement to the Hirshfeld surfaces. ${ }^{22}$ Such plots provide information about the intermolecular interactions in the immediate environment of each molecule in the asymmetric unit. Moreover, the close contacts between particular atom types can be highlighted in so-called resolved fingerprint plots ${ }^{23}$ which allows the facile assignment of an intermolecular contact to a certain type of interaction and quantitatively summarize the nature and type of intermolecular contacts. Two additional coloured properties (shape index and curvedness) based on the local curvature of the surface can also be specified. ${ }^{39}$ The Hirshfeld surfaces are mapped with $d_{\text {norm }}$, shape-index, curvedness and 2D fingerprint plots (full and resolved) presented in this paper were generated using CrystalExplorer 3.1..$^{40}$

\section{Results and Discussion}

\section{1. FT-IR Spectra}

The FT-IR spectrum of $\mathbf{1}$ shows a broad band centered around $3424 \mathrm{~cm}^{-1}$ assignable to $\bar{v}_{\text {str }}(\mathrm{O}-\mathrm{H})$ vibration of coordinated and/or lattice water. ${ }^{16}$ The observed position of $\bar{v}_{\text {str }}(\mathrm{O}-\mathrm{H})$ vibration indicates that lattice and coordinated water molecules are involved in hydrogen bonding which is confirmed by X-ray structure determination of the complex. The characteristic band corresponds to carboxyl stretching of free 2,4-pydc (appears at $1708 \mathrm{~cm}^{-1}$ in the spectrum of the pyridine-2,4-dicarboxylic acid) is absent in the spectrum of $\mathbf{1}$ indicatingd its coordination to the metal. The $\bar{v}_{\text {asym }}\left(\mathrm{COO}^{-}\right)$stretching vibration of the carboxylate group appears as two strong bands at 1651 and $1605 \mathrm{~cm}^{-1}$. The $\bar{v}_{\text {sym }}\left(\mathrm{COO}^{-}\right)$stretching vibration of the carboxylate group for $\mathbf{1}$ appears as single strong band at $1367 \mathrm{~cm}^{-1}$. The difference in wavenumber $(\Delta \bar{v})$ between the asymmetric and symmetric vibrations are greater than $200 \mathrm{~cm}^{-1}$ (284 and $238 \mathrm{~cm}^{-1}$ for $\mathbf{1}$ ), indicating that carboxylate group adopts unidentate coordination to the metal ion. ${ }^{2,41}$ The splitting of asymmetric stretching vibration to two well separated bands also indicates altogether different behavior of the carboxylate group. ${ }^{2}$ These suppositions are verified by structural analysis of the complex which reveal that one carboxylate group chelates the metal in a unidentate manner while the other craboxylate group remains uncoordinated. Several strong bands observed in the range $2914-3318 \mathrm{~cm}^{-1}$ may be assigned to $\bar{v}$ $(\mathrm{N}-\mathrm{H})$ stretching vibration of $\mathrm{NH}_{2}$ group (Supplementary Information: Figure S1). ${ }^{42}$

\section{2. UV-Visible Spectra}

Solid-state electronic spectrum of the title complex is recorded at room temperature in the wavelength 1100-200 nm. Spectrum of 1 (Supplementary Information: Figure S2) shows two strong bands at 266 and 288 $\mathrm{nm}$ corresponding to $\pi \rightarrow \pi^{*}$ transition of the coordinated ligands. A shoulder band around $369 \mathrm{~nm}$ corresponds to the $n \rightarrow \pi^{*}$ transition of the coordinated ligand is also observed in the spectrum of $\mathbf{1}$. In addition, a low intensity broad band centered around $610 \mathrm{~nm}$ is observed in the spectrum of 1 which is attributed to the $\mathrm{d} \rightarrow \mathrm{d}$ transition of the copper(II) atom with distorted square-pyramidal geometry. 


\section{3. Crystal Structure}

An ORTEP view of $\mathbf{1}$ with atom labels is shown in Figure 1. Asymmetric unit of $\mathbf{1}$ consists of a copper(II) atom, a neutral ligand (pic), a dianionic ligand (2,4-pydc) and two water molecules.
N3) towards apical oxygen (O1) by $0.261 \AA$. All donor atoms constructing the mean basal plane are coplanar within $\pm 0.131 \AA$. The $\mathrm{Cu}-\mathrm{N}$ and $\mathrm{Cu}-\mathrm{O}$ bond distances found for $\mathbf{1}$ are also very close to the similar complexes reported in the literature. .,3,13,16,17 $^{\text {The distorted square pyramidal }}$

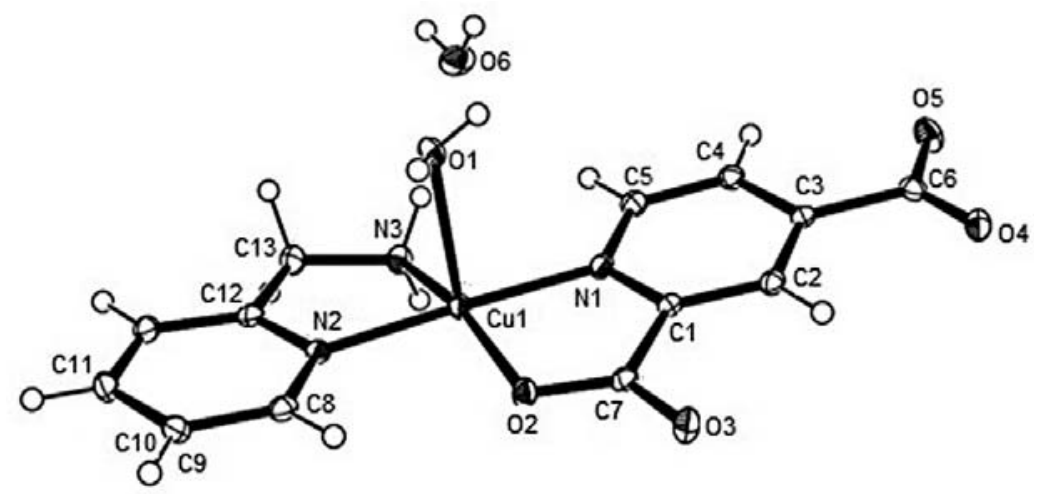

Figure 1: An ORTEP view of 1. Displacement ellipsoids are drawn at 30\% probability level.

Copper(II) ion is bis chelated by both pic and 2,4pydc and a water molecule is coordinated in monodentate fashion. Thus, copper(II) ion is five coordinated and the geometry is best described as distorted square-pyramid where two basal coordination sites are occupied by one pyridine nitrogen (N2) and primary aliphatic amine nitrogen $(\mathrm{N} 3)$ of the chelating pic ligand while the other two basal coordination sites are satisfied by pyridine nitrogen (N1) and one oxygen atom (O2) of the ortho-positioned carboxylate group of the 2,4-pydc. The apex position of the square-pyramid is occupied by oxygen atom (O1) of the coordinated water. The basal $\mathrm{Cu} 1-\mathrm{N}$ (pyridine) bond distances vary in the range 1.991(3)-1.989(3) $\AA$ while the other basal and apical $\mathrm{Cu} 1-\mathrm{O}$ bond distances vary in the range 1.970(2)-2.244(2) $\AA$. The trans basal angles (vary in the range $164.87(10)-176.84(10)^{\circ}$ ) and cis angles (vary in the range $\left.83.03(9)-101.10(9)^{\circ}\right)$ deviate from their ideal values of $180^{\circ}$ and $90^{\circ}$, respectively (Table 2 ).

The distorted square-pyramidal geometry of $\mathbf{1}$ is also evident from the relative deviation of metal ion from the mean-basal plane. The central $\mathrm{Cu} 1$ is slightly deviated from the mean basal plane (donor atoms: N1, O2, N2, and

Table 2. Selected bond length $(\AA)$ and bond angle $\left(^{\circ}\right)$ for $\mathbf{1}$

\begin{tabular}{lrcc}
\hline $\mathrm{Cu} 1-\mathrm{O} 1$ & $2.244(2)$ & $\mathrm{O} 2-\mathrm{Cu} 1-\mathrm{N} 1$ & $83.03(9)$ \\
$\mathrm{Cu} 1-\mathrm{O} 2$ & $1.970(2)$ & $\mathrm{N} 2-\mathrm{Cu} 1-\mathrm{N} 1$ & $176.84(10)$ \\
$\mathrm{Cu} 1-\mathrm{N} 1$ & $2.002(3)$ & $\mathrm{N} 3-\mathrm{Cu} 1-\mathrm{N} 1$ & $99.04(10)$ \\
$\mathrm{Cu} 1-\mathrm{N} 2$ & $1.989(3)$ & $\mathrm{O} 2-\mathrm{Cu} 1-\mathrm{O} 1$ & $101.10(9)$ \\
$\mathrm{Cu} 1-\mathrm{N} 3$ & $1.991(3)$ & $\mathrm{N} 2-\mathrm{Cu} 1-\mathrm{O} 1$ & $89.66(10)$ \\
$\mathrm{O} 2-\mathrm{Cu} 1-\mathrm{N} 2$ & $93.82(10)$ & $\mathrm{N} 3-\mathrm{Cu} 1-\mathrm{O} 1$ & $93.87(10)$ \\
$\mathrm{O} 2-\mathrm{Cu} 1-\mathrm{N} 3$ & $164.87(10)$ & $\mathrm{N} 1-\mathrm{Cu} 1-\mathrm{O} 1$ & $90.81(10)$ \\
$\mathrm{N} 2-\mathrm{Cu} 1-\mathrm{N} 3$ & $84.04(11)$ & & \\
\hline
\end{tabular}

geometry of copper(II) ion is evidenced by the trigonal in$\operatorname{dex} \tau=0.1996$. The value of the trigonal index $\tau$ is defined as the difference between the two largest donor-metal-donor angles divided by 60 to give a value of 0 for an ideal square pyramid and 1 for a trigonal bipyramid. ${ }^{43}$

Crystal packing of $\mathbf{1}$ viewed along $b c$-plane (Figure 2) reveals interesting hydrogen bonding. The complex contains several sufficiently electronegative centers capable of serving as proton donors/acceptors for the formation of several classical hydrogen bonds. These centers are mainly carboxylate oxygen atoms, amine nitrogen atoms, and the oxygen atoms of the coordinated and lattice water.

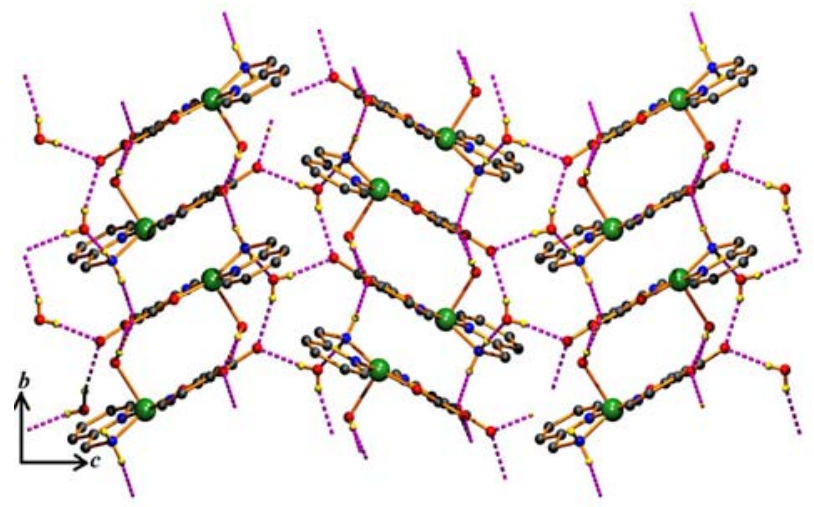

Figure 2: Packing diagram of 1 viewed along $b c$-plane showing different $\mathrm{O}-\mathrm{H} \cdots \mathrm{O}$ and $\mathrm{N}-\mathrm{H} \cdots \mathrm{O}$ hydrogen bonds.

Complex unit, lattice water and neighboring units are connected to each other via various $\mathrm{O}-\mathrm{H} \cdots \mathrm{O}$ and $\mathrm{N}-\mathrm{H} \cdots \mathrm{O}$ interactions (Table 3 ). Figure 2 shows two different intermolecular hydrogen bond motifs, a chain and 
ring. The chain motif is mainly created by hydrogen bonds between lattice water and non-coordinated carboxylate oxygen. There are five different types of ring motifs. According to Etter's graph set notation, ${ }^{17}$ they are designated as $R_{3}^{5}(12), R_{3}^{3}(10), R_{2}^{2}(18), R_{4}^{4}(22)$, and $R_{3}^{3}(20)$. The first ring motif involves non-coordinated carboxylate oxygen, amine hydrogen and lattice water molecule. The second ring motif involves lattice and coordinated water, amine hydrogen and non-coordinated carboxylate oxygen. The third ring motif involves coordinated water and non-coordinated carboxylate oxygen. The fourth ring motif involves amine hydrogen, lattice water and non-coordinated carboxylate oxygen while the fifth ring motif involves amine hydrogen, lattice and coordinated water and non-coordinated carboxylate oxygen. These hydrogen bonding is robust and lead to a three dimensional supramolecular structure which is further stabilized by $\mathrm{C}-\mathrm{H} \cdots \mathrm{O}$ and $\mathrm{C}-\mathrm{H} \cdots \pi$ interactions (Table 3 ).

Table 3. Hydrogen bonding and $\pi$ stacking interactions $\left(\AA,^{\circ}\right)$ for $\mathbf{1}$

\begin{tabular}{|c|c|c|c|c|}
\hline D-H...A & $d(\mathbf{D}-\mathbf{H})$ & $d($ H...A) & $d(\mathrm{D} . . . \mathrm{A})$ & $\angle \mathrm{D}-\mathrm{H} . . . \mathrm{A}$ \\
\hline 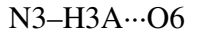 & 0.92 & 1.97 & $2.887(4)$ & 176 \\
\hline $\mathrm{N} 3-\mathrm{H} 3 \mathrm{~B} \cdots \mathrm{O} 5^{\mathrm{i}}$ & 0.92 & 2.36 & $3.146(3)$ & 144 \\
\hline $\mathrm{O} 1-\mathrm{H} 80 \cdots \mathrm{O}^{\mathrm{ii}}$ & $0.75(4)$ & $1.98(4)$ & $2.721(4)$ & $169(4)$ \\
\hline $\mathrm{O} 1-\mathrm{H} 81 \cdots \mathrm{O} 3^{\mathrm{iii}}$ & $0.76(4)$ & 1.91(4) & $2.671(4)$ & $177(5)$ \\
\hline $\mathrm{O} 6-\mathrm{H} 82 \cdots \mathrm{O} 4^{\mathrm{iv}}$ & $0.73(6)$ & $2.08(5)$ & $2.801(4)$ & $170(5)$ \\
\hline $\mathrm{O} 6-\mathrm{H} 83 \cdots \mathrm{O} 4^{\mathrm{ii}}$ & $0.74(5)$ & $2.13(5)$ & $2.837(4)$ & $162(4)$ \\
\hline 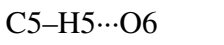 & 0.95 & 2.46 & $3.263(4)$ & 142 \\
\hline $\mathrm{C} 13-\mathrm{H} 13 \mathrm{~B} \cdots \mathrm{O} 1^{\mathrm{v}}$ & 0.99 & 2.52 & $3.304(4)$ & 136 \\
\hline $\mathrm{C} 11-\mathrm{H} 11 \cdots \pi$ & 0.95 & 2.76 & $3.575(3)$ & 144 \\
\hline
\end{tabular}

Symmetry codes: ( $\left.{ }^{\mathrm{i}}\right)-x,-y, 1-z$ (ii) $^{\mathrm{ii}}-x,-y,-z$ (iii) $1-x,-y,-z$ ( $\left.^{\mathrm{iv}}\right)$ $-x, 1 / 2+y, 1 / 2-z\left(^{v}\right) x, 1 / 2-y, 1 / 2+z$

\section{4. Hirshfeld Surface Analyses}

The Hirshfeld surfaces are unique for a particular crystal structure and its numbers also depend on the number of crystallographically independent molecules in the corresponding asymmetric unit. ${ }^{44}$ The molecular Hirshfeld surface; $d_{\text {norm, }}$, shape index and curvedness for $\mathbf{1}$ is illustrated in Figures 3-5, respectively, and mapped over $d_{\text {norm }}$ ranges -0.7145 to $1.1610 \AA$, shape index ranges -0.9954 to $0.9965 \AA$, and curvedness ranges -4.9685 to $0.4142 \AA$, respectively. The $d_{\text {norm }}$ mapping indicates that strong hydrogen bond interactions, such as $\mathrm{O}-\mathrm{H} \cdots \mathrm{O}$ hydrogen bonding between coordinated/lattice water and carboxylato oxygen and $\mathrm{N}-\mathrm{H} \cdots \mathrm{O}$ hydrogen bonding between amino group and lattice water oxygen or carboxylato oxygen, appear as primary interaction between the complexes, seen as a bright red area in the Hirshfeld surfaces (Figure 3).

The shape index is the most sensitive to very subtle changes in surface shape, the red triangles on them (above the plane of the molecule) represent by concave regions

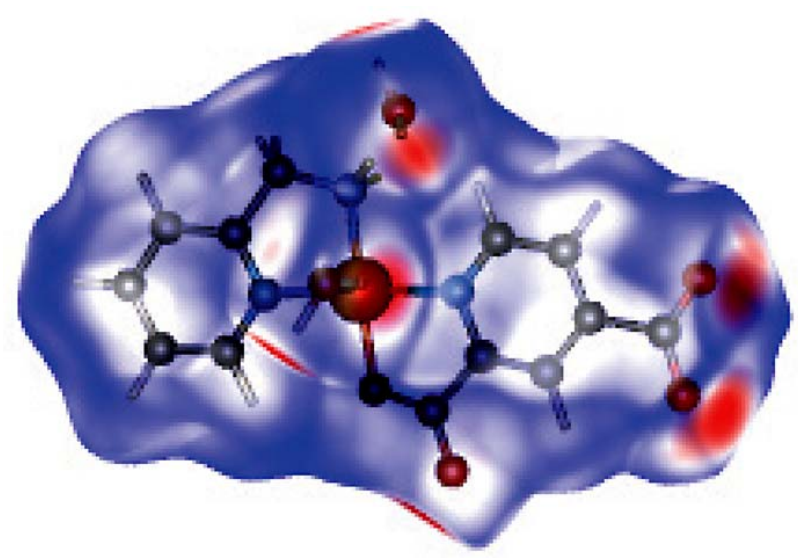

Figure 3: Molecular Hirshfeld surface: $d_{\text {norm }}$ for 1.

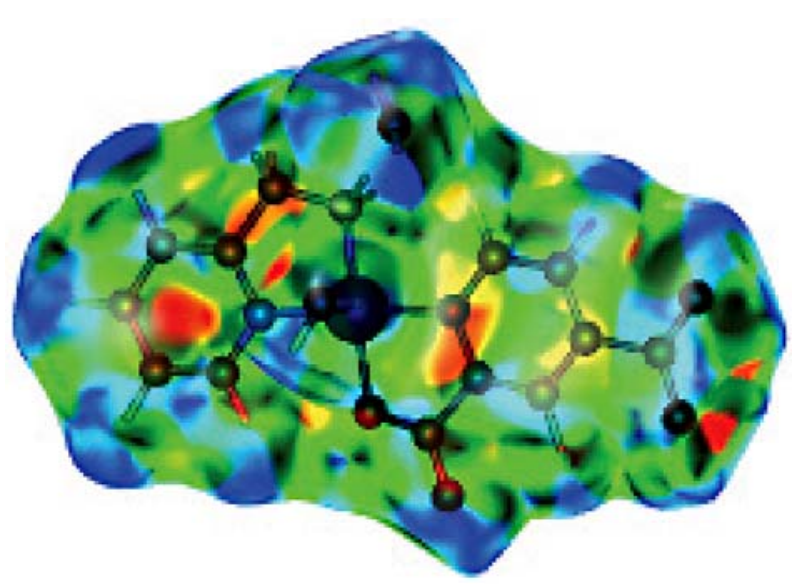

Figure 4: Molecular Hirshfeld surface: Shape index for 1.

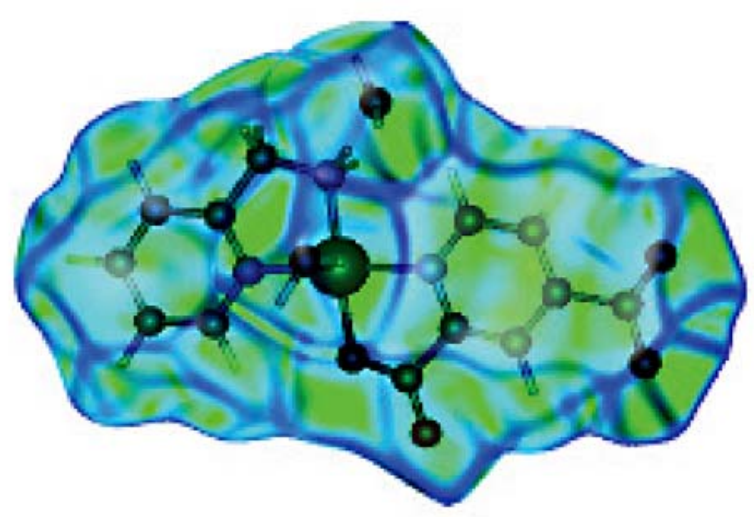

Figure 5: Molecular Hirshfeld surface: Curvedness for1.

indicating atoms of the $\pi$-stacked molecule above them, and the blue triangles represent by convex regions indicating the ring atoms of the molecule inside the surfaces. The red triangles on the shape index mapping are referring to the $\mathrm{C} 11-\mathrm{H} 11 \cdots \pi$ interaction with the contribution of $14.4 \%$ (Table 4 ) and the information conveyed by sha- 
pe index is in agreement with the $2 \mathrm{D}$ fingerprint plot ( $\mathrm{Fi}$ gure 6$).{ }^{45,46}$

The curvedness is a measure of the shape of the surface area of the molecule. The flat areas of the surface correspond to low values of curvedness, while sharp curvature areas correspond to high values of curvedness and usually tend to divide the surface into patches, indicating interactions between neighboring molecules. The large flat region which delineated by a blue outline refer to the $\pi \cdots \pi$ stacking interactions. The curvedness of the complex reveals that $\pi \cdots \pi$ stacking interaction is absent. ${ }^{45,46}$

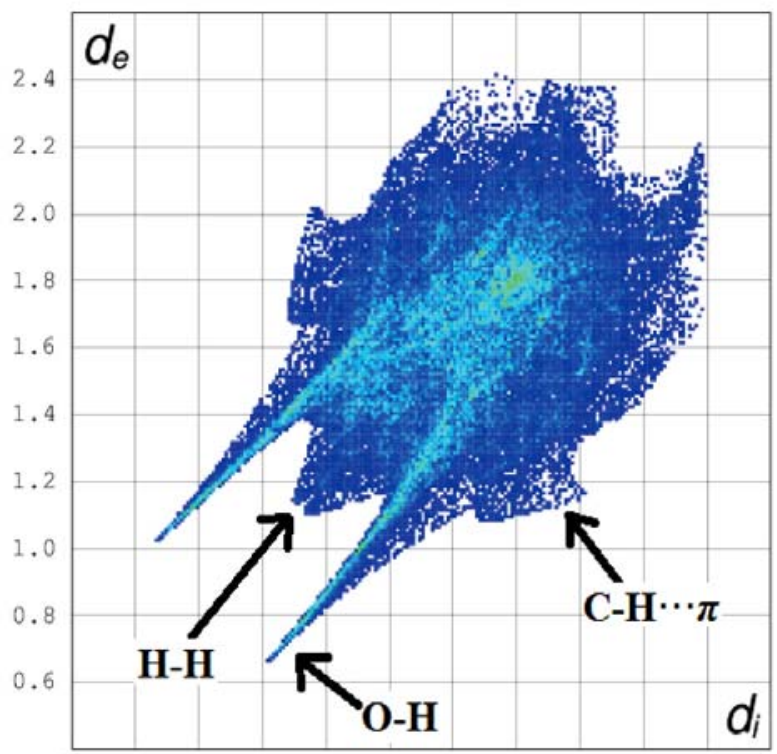

(A) $\quad \begin{array}{llllllllllllll}0.6 & 0.8 & 1.0 & 1.2 & 1.4 & 1.6 & 1.8 & 2.0 & 2.2 & 2.4\end{array}$

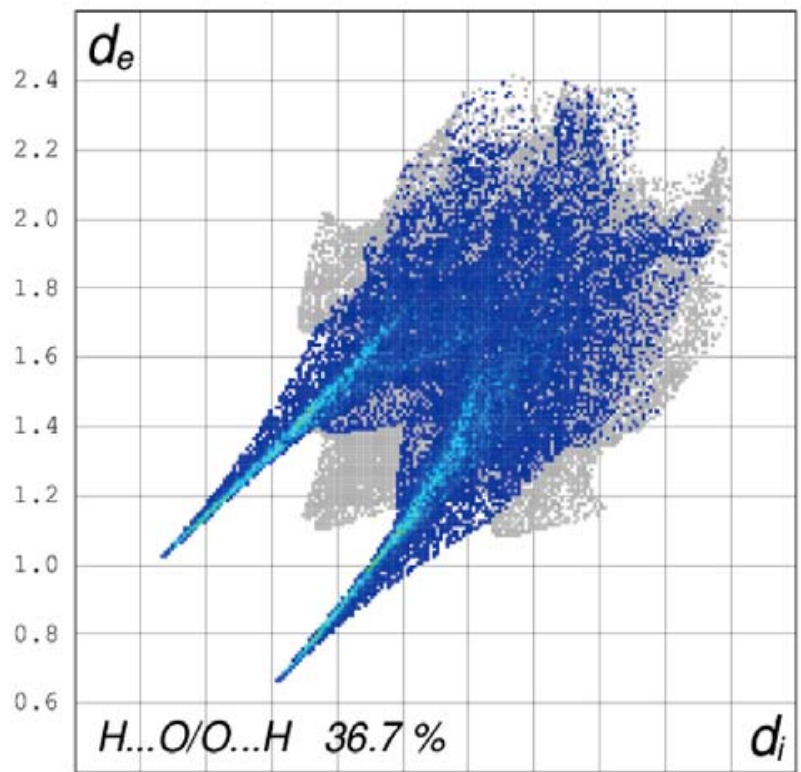

(A) $\quad \begin{array}{lllllllllllll}0.6 & 0.8 & 1.0 & 1.2 & 1.4 & 1.6 & 1.8 & 2.0 & 2.2 & 2.4\end{array}$
The 2D fingerprint plots for 1 (Figure 6 ) show that the intermolecular $\mathrm{H} \cdots \mathrm{H}, \mathrm{O}-\mathrm{H} \cdots \mathrm{O}$, and $\mathrm{C}-\mathrm{H} \cdots \pi$ interactions are well dominated and are in complement to the Hirshfeld surfaces. The fingerprint plots can also be decomposed to highlight particular atoms pair close contacts ${ }^{45}$ and enables separation of contributions from different interaction types. Two sharp spikes pointing towards lower left of the plot are typical $\mathrm{O}-\mathrm{H} \cdots \mathrm{O}$ hydrogen bonds. This portion corresponds to $\mathrm{H}-\mathrm{O} / \mathrm{O}-\mathrm{H}$ interactions comprising $36.7 \%$ of the total Hirshfed surfaces for each molecule of $\mathbf{1}$. At the top left of the plot, there are characteristic "wings" which are identified as a result of $\mathrm{C}-\mathrm{H} \cdots \pi$ interactions.

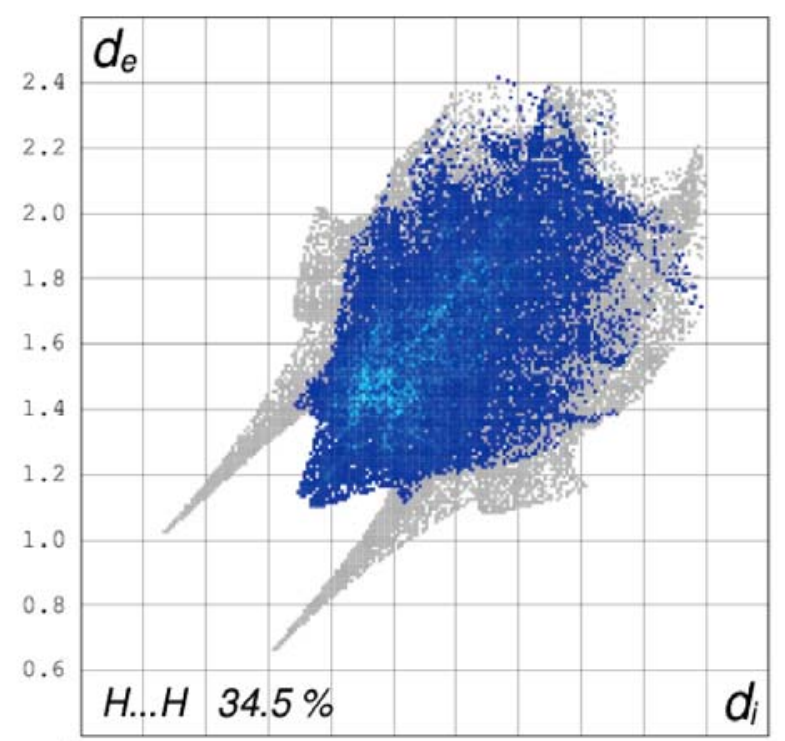

(A) $\quad \begin{array}{lllllllllllll}0.6 & 0.8 & 1.0 & 1.2 & 1.4 & 1.6 & 1.8 & 2.0 & 2.2 & 2.4\end{array}$

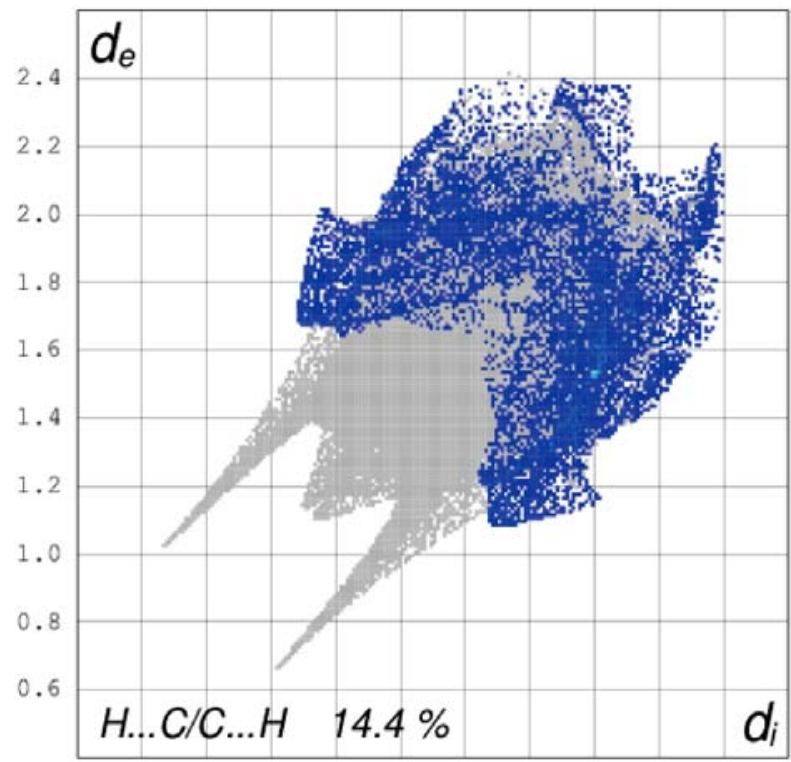

(A) $\quad \begin{array}{lllllllllll}0.6 & 0.8 & 1.0 & 1.2 & 1.4 & 1.6 & 1.8 & 2.0 & 2.2 & 2.4\end{array}$

Figure 6: Fingerprint plot of 1: full and resolved into $\mathrm{H} \cdots \mathrm{H}, \mathrm{H} \cdots \mathrm{O}$ and $\mathrm{H} \cdots \mathrm{C}$ contacts showing the percentages of contacts contributed to the total Hirshfeld surface area. 
Table 4. Summary of various contacts and their contributions to the Hirshfeld Surface in 1

\begin{tabular}{cc}
\hline Types of contacts & Contributions in\% \\
\hline $\mathrm{H} \cdots \mathrm{H}$ & 34.5 \\
$\mathrm{~N} \cdots \mathrm{H}$ & 0.8 \\
$\mathrm{C} \cdots \mathrm{H}$ & 14.4 \\
$\mathrm{O} \cdots \mathrm{H}$ & 36.7 \\
$\mathrm{H} \cdots \mathrm{M}$ & 0.1 \\
$\mathrm{O} \cdots \mathrm{M}$ & 0.7 \\
$\mathrm{~N} \cdots \mathrm{C}$ & 1.0 \\
$\mathrm{C} \cdots \mathrm{O}$ & 2.9 \\
$\mathrm{~N} \cdots \mathrm{O}$ & 0.3 \\
$\mathrm{O} \cdots \mathrm{O}$ & 0.6 \\
$\mathrm{C} \cdots \mathrm{C}$ & 5.2 \\
\hline
\end{tabular}

The decomposition of the fingerprint plots show that $\mathrm{H}-\mathrm{C} / \mathrm{C}-\mathrm{H}$ contacts comprise $14.4 \%$ of the total Hirshfeld surface area for the molecule of $\mathbf{1}$. They correspond to all $\mathrm{C}-\mathrm{H} \cdots \mathrm{C}$ interactions of which $\mathrm{C}-\mathrm{H} \cdots \pi$ appear in the fingerprint plot in a characteristic manner. The broad region bearing short and narrow spikes at the middle of plot is reflected as $\mathrm{H} \cdots \mathrm{H}$ interaction in $\mathbf{1}$ comprising $34.5 \%$ of the total Hirshfeld surfaces for 1. Apart from these above, the presence of $\mathrm{N} \cdots \mathrm{H}, \mathrm{C} \cdots \mathrm{O}, \mathrm{N} \cdots \mathrm{O}, \mathrm{O} \cdots \mathrm{O}, \mathrm{C} \cdots \mathrm{C}, \mathrm{H} \cdots \mathrm{M}$, $\mathrm{O} \cdots \mathrm{M}$, and $\mathrm{N} \cdots \mathrm{C}$ interactions were observed, which are summarized in Table $4 .^{46-48}$

\section{5. Powder XRD Data}

The experimental powder XRD pattern of the bulk product of the complex is in good agreement with the simulated XRD pattern obtained from single crystal X-ray diffraction, confirming phase purity of the bulk sample (Supplementary Information: Figure S3). The simulated pattern was calculated from the single crystal structural data (cif file) using the CCDC Mercury software.

\section{6. Thermogravimetric Analysis}

Thermogravimetric analysis (Supplementary Information: Figure S4) reveals thermal stabilities of the complex when heated in the temperature range 35-800 ${ }^{\circ} \mathrm{C}$ in dynamic nitrogen atmosphere. TG curve for $\mathbf{1}$ reveals that the complex is thermally stable up to $105{ }^{\circ} \mathrm{C}$. Then it undergoes a mass loss of ca. $9.62 \%$ (calcd. $9.66 \%$ ) corresponds to the loss of both crystalline and coordinated water in the temperature range $105-200{ }^{\circ} \mathrm{C}$. The dehydrated complex remains stable up to $226{ }^{\circ} \mathrm{C}$. Thereafter it undergoes a continuous weight loss up to ca. $600{ }^{\circ} \mathrm{C}$ due to its decomposition. The mass loss of ca. $74.52 \%$ (calcd. $76.40 \%$ ) corresponds well to the loss of the coordinated ligand. Dehydrated complex decomposes steadily in three steps, 226-252, 252-282, and $282-600{ }^{\circ} \mathrm{C}$. No further weight loss is observed upon heating up to $800{ }^{\circ} \mathrm{C}$.

\section{Conclusion}

In this paper we have reported the synthesis, characterization and crystal structure of a new coordination complex of copper(II) incorporating pyridine-2,4-dicarboxylate and 2-picolylamine. Structural characterization reveals that copper(II) atom adopts distorted square pyramidal geometry. Structural characterization also reveals that the primary structural motifs that constitute the backbone of the net supramolecular arrangement are dictated by hydrogen bonds whereas weaker $\mathrm{H} \cdots \mathrm{H}$ and $\mathrm{C}-\mathrm{H} \cdots \pi$ stacking interactions are found to govern the final solidstate packing, resulting 3D supramolecular structure. The molecular Hirshfeld surface and 2D fingerprint plots were used for quantitative mapping out these interactions.

\section{Acknowledgments}

S. Shit gratefully acknowledges University Grants Commission, New Delhi, India for financial assistance (Minor Research Project No. F. PSW-65/12-13 (ERO)). Thanks are also extended to the University Grants Commission, New Delhi, for financial assistance to Prof. S. Mitra as Emeritus Fellow to carry out this work.

\section{1. Appendix: Supplementary Materials}

Crystallographic data for $\mathbf{1}$ reported in this paper have been deposited with the Cambridge Crystallographic Data Centre, CCDC, 12 Union Road, Cambridge CB21EZ, UK. Copies of the data can be obtained free of charge on quoting the depository numbers CCDC-1023872 (1) (Fax: +44-1223-336-033; E-Mail: deposit@ ccdc.cam.ac.uk, http://www.ccdc.cam.ac.uk).

\section{References}

1. F.-J. Meng, H.-Q. Jia, N.-H. Hu, J.-W. Xu, Inorg. Chem. Commun. 2012, 21, 186-190, and references therein. http://dx.doi.org/10.1016/j.inoche.2012.04.012

2. S. Yan, X. Li, X. Zheng, J. Mol. Struct. 2009, 929, 105-111. http://dx.doi.org/10.1016/j.molstruc.2009.04.012

3. K. L. Gurunatha, T. K. Maji, Eur. J. Inorg. Chem. 2009, 1592-1599. http://dx.doi.org/10.1002/ejic.200801153

4. S.-X. Cui, Y.-L. Zhao, J.-P. Zhang, Q. Liu, Y. Zhang, Polyhedron 2009, 28, 980-986.

http://dx.doi.org/10.1016/j.poly.2008.12.051

5. L. Chen, X.-M. Lin, Y. Ying, Q.-G. Zhan, Z.-H. Hong, J.-Y. Li, N. S. Weng, Y.-P. Cai, Inorg. Chem. Commun. 2009, 12, 761-765. http://dx.doi.org/10.1016/j.inoche.2009.06.009

6. S. S. Massoud, P. J. Deifik, P. K. Bankole, R. Lalancette, G. Yee, D. Tatum, I. Bernal, F. A. Mautner, Inorg. Chim. Acta 2010, 363, 1001-1007.

http://dx.doi.org/10.1016/j.ica.2009.12.023 
7. M. Gryz, W. Starosta, J. Leciejewicz, J. Coord. Chem. 2005, 58, 931-935. http://dx.doi.org/10.1080/00958970500055492

8. S. S. Massoud, F. R. Louka, L. T. Nguyen, M. Mikuriya, J.H. Albering, F. A. Mautner, Inorg. Chim. Acta 2011, 366, 394 398. http://dx.doi.org/10.1016/j.ica.2010.11.014

9. L.-F. Chen, X.-Y. Cao, Z .-J. Li, J.-K. Cheng, Q.-P. Lin, Y.-G Yao, Inorg. Chem. Commum. 2008, 11, 961-964. http://dx.doi.org/10.1016/j.inoche.2008.05.011

10. P. King, R. Clérac, C. E. Anson, A. K. Powel, Dalton Trans. 2004, 852-861. http://dx.doi.org/10.1039/b315067d

11. P. King, R. Clérac, C. E. Anson, C. Coulon, A. K. Powel, Inorg. Chem. 2003, 42, 492-3500.

http://dx.doi.org/10.1021/ic025619b

12. J.-L. Tian, S.-P. Yan, D.-Z. Liao, Z .-H. Jiang, P. Cheng, Inorg. Chem. Commun. 2003, 6, 1025-1029. http://dx.doi.org/10.1016/S1387-7003(03)00174-6

13. A. Das, G. Pilet, D. Luneau, M. S. El Fallah, J. Ribas, S. Mitra, Inorg. Chim. Acta 2005, 358, 4581-4587. http://dx.doi.org/10.1016/j.ica.2005.07.036

14. W. Zhuang, X. Zheng, L. Li, D. Liao, H. Ma, L. Jin, CrystEngComm. 2007, 9, 653-667. http://dx.doi.org/10.1039/b703429f

15. L. F. Ma, L. Y. Wang, M. Du, S. R. Batten, Inorg. Chem. 2010, 49, 365-367. http://dx.doi.org/10.1021/ic9019298

16. F. A. Mautner, J. H. Albering, M. Corbella, S. S. Massoud, Inorg. Chem. Commun. 2011, 14, 702-705, and references therein. http://dx.doi.org/10.1016/j.inoche.2011.02.011

17. S. Shit, J. Chakraborty, S. Sen, G. Pilet, C. Desplanches, S. Mitra, J. Mol. Struct. 2008, 891, 19-24, and references therein. http://dx.doi.org/10.1016/j.molstruc.2008.02.027

18. B. T. Tu, H. L. Zhu, G. He, Y. Chen, B. Hu, J. Z. Chen, Russian J. Coord. Chem. 2011, 37, 696-700. http://dx.doi.org/10.1134/S1070328411080112

19. S. K. Seth, D. Sarkar, T. Kar, CrystEngComm. 2011, 13, 4528-4535. http://dx.doi.org/10.1039/c1ce05037k

20. K. Nørgaard, T. Bjørnholm, Chem. Commun. 2005, 18121823. http://dx.doi.org/10.1039/b417526n

21. C. J. Kepert, Chem. Commun. 2006, 695-700. http://dx.doi.org/10.1039/b515713g

22. M. A. Spackman, J. J. McKinnon, CrystEngComm. 2002, 4, 378-392. http://dx.doi.org/10.1039/b203191b

23. J. J. McKinnon, D. Jayatilaka, M. A. Spackman, Chem. Commun. 2007, 3814-3816. http://dx.doi.org/10.1039/b704980

24. M. A. Spackman, J. J. McKinnon, D. Jayatilaka, CrystEngComm. 2008, 10, 377-388.

25. M. A. Spackman, D. Jayatilaka, CrystEngComm. 2009, 11, 19-32. http://dx.doi.org/10.1039/B818330A

26. F. L. Hirshfeld, Theor. Chim. Acta 1977, 44, 129-138. http://dx.doi.org/10.1007/BF00549096

27. A. D. Martin, K. J. Hartlieb, A. N. Sobolev, C. L. Raston, Cryst. Growth Des. 2010, 10, 5302-5306. http://dx.doi.org/10.1021/cg1011605

28. A. L. Rohl, M. Moret, W. Kaminsky, K. Claborn, J. J. Mckinnon, B. Kahr, Cryst. Growth Des. 2008, 8, 4517-4525. http://dx.doi.org/10.1021/cg8005212

29. A. Parkin, G. Barr, W. Dong, C. J. Gilmore, D. Jayatilaka, J. J. Mckinnon, M. A. Spackman, C. C. Wilson, CrystEngComm. 2007, 9, 648-652.

http://dx.doi.org/10.1039/b704177b

30. SMART, Data Collection Program for the CCD Area Detector System.

31. G. M. Sheldrick, SADABS, Program for Empirical Absorption Correction of Area Detector Data, University of Göttingen, Göttingen (Germany) 1996.

32. SAINT, Data Reduction, Frame Integration Program for the CCD Area Detector System, Bruker Analytical X-ray Instruments Inc., Madison, Wisconsin (U.S.A.) 2005.

33. G. M. Sheldrick, Acta Cryst. 2008, A64, 112-122. http://dx.doi.org/10.1107/S0108767307043930

34. L. J. Farrugia, J. Appl. Crystallogr. 1997, 30, 565-566. http://dx.doi.org/10.1107/S0021889897003117

35. G. M. Sheldrick, SHELXTL (version 5.1), Program for the Solution and Refinement of Crystal Structures, Bruker Analytical X-ray Instruments Inc., Madison, Wisconsin (U.S.A.) 1999.

http://dx.doi.org/10.1002/(SICI)1521-3765(19981102)4:11 $<2136$ ::AID-CHEM2136>3.0.CO;2-G

36. J. J. McKinnon, A. S. Mitchell, M. A. Spackman, Chem.-Eur. J. 1998, 4, 2136-2141.

37. M. A. Spackman, P. G. Byrom, Chem. Phys. Lett. 1997, 267, 215-220. http://dx.doi.org/10.1016/S0009-2614(97)00100-0

38. I. D. Madura, J. Zachara, H. Hajmowicz, L. Synoradzki, J. Mol. Struct. 2012, 1017, 98-105.

http://dx.doi.org/10.1016/j.molstruc.2012.02.053

39. J. J. Koenderink, A. J. van Doorn, Image Vision Comput. 1992, 10, 557-564. http://dx.doi.org/10.1016/0262-8856(92)90076-F

40. S. K. Wolff, D. J. Grimwood, J. J. Mckinnon, M. J. Turner, D. Jayatilaka, M. A. Spackman, Crystal Explorer 2.2., University of Western Australia 2010.

41. K. Nakamoto, Infrared and Raman Spectra of Inorganic and Coordination Compounds, $4^{\text {th }}$ ed. Wiley \& Sons Interscience Publ. New York 1986.

42. R. Karmakar, C. R. Choudhury, V. Gramlich, S. Mitra, Inorg. Chim. Acta 2004, 357, 3785-3788. http://dx.doi.org/10.1016/j.ica.2004.05.026

43. A. W. Addison, T. N. Rao, J. Reedijk, J. van Rijn, G. C. Verschoor, J. Chem. Soc. Dalton Trans. 1984, 1349-1356. http://dx.doi.org/10.1039/dt9840001349

44. J. J. McKinnon, F. P. A. Fabbiani, M. A. Spackman, Cryst. Growth Des. 2007, 7, 755-769. http://dx.doi.org/10.1021/cg060773k

45. Y.-H. Luo, G.-G. Wu, S.-L. Mao, B.-W. Sun, Inorg. Chim. Acta 2013, 397, 1-9. http://dx.doi.org/10.1016/j.ica.2012.11.010

46. Y. Li, C. -G. Zhang, L. -Y. Cai, Z. -X. Wang, J. Coord. Chem. 2013, 66, 3100-3112. http://dx.doi.org/10.1080/00958972.2013.826350

47. Y.-H. Luo, B.-W. Sun, Spectrochim. Acta 2014, 120 A, 381-388. 
48. S. K. Seth, P. C. Mandal, T. Kar, S. Mukhopadhyay, J. Mol. Struct. 2011, 994, 109-116.

http://dx.doi.org/10.1016/j.molstruc.2011.03.004

\section{Povzetek}

Sintetizirali smo nov bakrov(II) kompleks z različnimi ligandi, $\left[\mathrm{Cu}(2,4-\right.$ pydc $)($ pic $\left.)\left(\mathrm{H}_{2} \mathrm{O}\right)\right] \cdot \mathrm{H}_{2} \mathrm{O}(\mathbf{1})(2,4-$ pydc $=$ piridin2,4-dikarboksilat, pic = 2-pikolilamin) in ga okarakterizirali z elementno analizo, FT-IR in UV-Vis spektroskopijo in termogravimetrično analizo. Rentgenska monokristalna difrakcija razkriva, da ima bakrov(II) atom popačeno kvadratno-piramidalno koordinacijo. Strukturna karakterizacija kaže na medsebojno delovanje $\mathrm{O}-\mathrm{H} \cdots \mathrm{O}, \mathrm{N}-\mathrm{H} \cdots \mathrm{O}, \mathrm{C}-\mathrm{H} \cdots \mathrm{O}$ in $\mathrm{C}-\mathrm{H} \cdots \pi$ interakcij med kristalno in koordinirano vodo ter ligandi, kar pomembno prispeva k kristalnemu pakiranju in vodi do tvorbe in ojačenja tridimenzionalne supramolekularne strukture. Hirshfeldova površinska analiza z uporabo 3D molekularnih površinskih kontur in 2D prstnih odtisov je bila uporabljena za analizo intermolekularnih interakcij, ki so prisotne $\mathrm{v}$ trdnem stanju. 